\title{
High BIM mRNA levels are associated with longer survival in advanced gastric cancer
}

\author{
NANDIE WU ${ }^{1 *}$, YING HUANG $^{1 *}$, ZHENGYUN ZOU $^{1}$, ANA GIMENEZ-CAPITAN ${ }^{2}$, \\ LIXIA YU ${ }^{1}$, WENJING HU ${ }^{1}$, LIJING ZHU ${ }^{1}$, XIA SUN ${ }^{1}$, JOSE JAVIER SANCHEZ ${ }^{3}$, \\ WENXIAN GUAN $^{4}$, BAORUI LIU ${ }^{1}$, RAFAEL ROSELL ${ }^{2,5}$ and JIA WEI ${ }^{1}$ \\ ${ }^{1}$ The Comprehensive Cancer Centre of Drum Tower Hospital, Department of Oncology, \\ The Affiliated Drum Tower Hospital of Nanjing University, Medical School of Nanjing University, \\ Clinical Cancer Institute of Nanjing University, Nanjing, Jiangsu 210008, P.R. China; ${ }^{2}$ Pangaea Biotech, \\ Department of Oncology, USP Dexeus University Institute, Barcelona 08001; \\ ${ }^{3}$ Department of Preventive Medicine and Public Health, Autonomous University of Madrid, Madrid 28001, Spain; \\ ${ }^{4}$ Department of General Surgery, The Affiliated Drum Tower Hospital of Nanjing University, \\ Medical School of Nanjing University, Nanjing, Jiangsu 210008, P.R. China; ${ }^{5}$ Department of Medical Oncology, \\ Catalan Institute of Oncology, Hospital Germans Trias i Pujol, Badalona, Barcelona 08916, Spain
}

Received March 31, 2015; Accepted April 22, 2016

DOI: $10.3892 / 01.2017 .5660$

\begin{abstract}
Chemotherapy drugs, including 5-fluorouracil(5-FU), oxaliplatin and docetaxel, are commonly used in the treatment of gastric cancer (GC). Apoptosis-relevant genes may be associated with drug resistance. In the present study, the messenger RNA (mRNA) expression levels of B-cell lymphoma 2 interacting mediator of cell death (BIM), astrocyte elevated gene-1 (AEG-1) and AXL receptor tyrosine kinase (AXL) were investigated in 131 advanced GC samples, and the expression levels of these genes were correlated with patients' overall survival (OS). All 131 patients received first-line FOLFOX combination chemotherapy with folinic acid and 5-FU, in which 56 patients were further treated with second-line docetaxel-based chemotherapy. A correlation between the mRNA expression levels of $\mathrm{BIM}$ and AEG-1 was observed $\left(r_{s}=0.30 ; \mathrm{P}=0.002\right)$. There was no association between the mRNA expression levels of any of the individual genes analyzed and OS in patients only receiving first-line FOLFOX chemotherapy. In a subgroup of patients receiving docetaxel-based second-line chemotherapy, those with high or intermediate levels of BIM exhibited a median
\end{abstract}

Correspondence to: Professor Jia Wei, The Comprehensive Cancer Centre of Drum Tower Hospital, Department of Oncology, The Affiliated Drum Tower Hospital of Nanjing University, Medical School of Nanjing University, Clinical Cancer Institute of Nanjing University, 321 Zhongshan Road, Nanjing, Jiangsu 210008, P.R. China

E-mail: weijia01627@hotmail.com

*Contributed equally

Key words: gene expression, BIM, second-line docetaxel-based chemotherapy, gastric cancer, apoptosis
OS of 18.2 months [95\% confidence interval (CI), 12.8-23.6], compared with 9.6 months (95\% CI, 8.9-10.3) in patients with low BIM levels $(\mathrm{P}=0.008)$. However, there was no correlation between the mRNA expression levels of AEG-1 or AXL and OS. The risk of mortality was higher in patients with low BIM mRNA levels than in those with high or intermediate BIM mRNA levels (hazard ratio, 2.61; 95\% CI, 1.21-5.62; $\mathrm{P}=0.010$ ). Therefore, BIM may be considered as a biomarker to identify whether patients could benefit from docetaxel-based second-line chemotherapy in GC.

\section{Introduction}

The incidence of gastric cancer (GC) ranks as the fifth most frequent among all types of cancer worldwide (1). Nearly $40 \%$ of all GC cases occur in China, and are often diagnosed in advanced stages (2). The median overall survival (OS) for GC patients remains $<12$ months with first-line oxaliplatin, 5-fluorouracil (5-FU) and folinic acid treatment (3). Of all GC patients, $\sim 1 / 2$ could be candidates for second-line treatment at the time of failure of first-line chemotherapy (4). Docetaxel is among the most frequently used agents for GC second-line treatment (5). In a previous study by the present authors, the median OS was 25.8 months for patients with high messenger RNA (mRNA) expression levels of breast cancer susceptibility gene 1 (BRCA1) treated with second-line docetaxel-based chemotherapy (6). Recent evidence also suggests that an underlying cause of drug resistance may be the failure of drug-induced apoptosis (7-9). Platinum treatment initiates apoptosis through the formation of DNA adducts, which primarily form intrastrand crosslinks that activate the apoptotic pathway, eventually resulting in cell death $(10,11)$. The most recognized mechanism of docetaxel-based regimen is the binding to microtubules, which arrests the cell cycle in G2/M and eventually leads to cell death (12). 
B-cell lymphoma 2 (BCL-2) interacting mediator of cell death (BIM) belongs to the BCL-2 protein family, and is also a member of the BCL-2-homology 3-only (BH3-only) family (13). BIM is expressed in a wide variety of tissues, including GC, and acts as a pivotal regulator of the mitochondrial apoptosis pathway (14). Abnormal levels of BIM have been recognized to affect the chemotherapy response (15). Platinum-resistant cancer cells conserved sensitivity to BH3-induced mitochondrial apoptosis (16). In line with that, BH3-mimetic compounds such as ABT-737 were able to sensitize cancer cells to platinum (17). In addition, overexpression of BIM enhanced the in vitro sensitivity to docetaxel of non-small cell lung cancer (NSCLC) (18). Consistent with this finding, downregulation of BIM by small interfering RNA (siRNA) delayed paclitaxel-mediated apoptosis, indicating that low BIM expression levels were responsible for resistance to paclitaxel (19). Notably, pre-treatment mRNA levels of BIM strongly predicted the capacity of epidermal growth factor receptor (EGFR), human EGFR 2 (HER2) and phosphoinositide 3-kinase (PI3K) inhibitors to induce apoptosis in EGFR-mutant, HER2-amplified and phosphatidylinositol-4,5-bisphosphate 3-kinase catalytic subunit alpha-mutant tumors, respectively (20). In a previous study, the present authors observed that patients with high BIM expression achieved longer survival in EGFR-mutant NSCLC treated with erlotinib or chemotherapy (21).

Astrocyte elevated gene-1 (AEG-1) was originally identified as a novel gene induced by human fetal astrocytes following infection with human immunodeficiency virus 1 (22). AEG-1 does not impact the uptake or retention of chemotherapy drugs; instead, AEG-1 increases chemoresistance by enhancing cell survival (23). Overexpression of AEG-1 suppresses apoptosis through phosphorylation of substrates of the anti-apoptotic protein kinase B (also known as AKT) (24), and is important in promoting cancer malignant behavior (25). In previous studies, AEG-1 overexpression correlated with poor prognosis in GC (25) and NSCLC (26). It has been confirmed that AEG-1 contributed to resistance to chemotherapeutic drugs such as $5-\mathrm{FU}$ in hepatocellular carcinoma cell lines (27). Furthermore, knockdown of AEG-1 sensitized breast cancer cell lines to paclitaxel in vitro and in vivo (23). Low AEG-1 expression was associated with longer progression-free survival in platinum-based chemotherapy in NSCLC (28). In addition, AEG-1 mRNA expression correlated with BRCA1 expression (28), which induced sensitivity to docetaxel (6).

AXL receptor tyrosine kinase (AXL) belongs to the Tyro3, AXL and Mer family (29). Growth arrest-specific gene 6 (Gas6) is the ligand of AXL (30). In conjunction with each other, Gas6/AXL signaling may enhance cell survival (31). Activation of Gas6/AXL signaling induced the activation of the PI3K signaling pathway, which increased the expression of anti-apoptotic proteins such as BCL-2 and BCL-extra large (BCL-XL) (32). Overexpression of AXL was responsible for tumor growth in mesothelioma (33), lung cancer (34) and breast cancer (35). Furthermore, increased AXL activation has been linked with cisplatin resistance in ovarian cancer (36).

In the present study, the mRNA expression levels of BIM, AEG-1 and AXL were examined in 131 advanced GC samples.
In addition, the expression levels of the above genes were correlated with patients' clinicopathological features and OS to first-line FOLFOX combination chemotherapy with folinic acid and 5-FU, with or without second-line docetaxel-based chemotherapy.

\section{Patients and methods}

Study population. A total of 131 advanced GC samples in which BRCA1 mRNA expression levels had been previously determined (6) were included in the present study. Patients' clinical characteristics are indicated in Table I. All patients received a combination of oxaliplatin, 5 -fluorouracil (FU) and folinic acid (FOLFOX) as first-line therapy $\left(85 \mathrm{mg} / \mathrm{m}^{2}\right.$ oxaliplatin plus $200 \mathrm{mg} / \mathrm{m}^{2}$ folinic acid and $600 \mathrm{mg} / \mathrm{m}^{2} 5$-FU every for 2 weeks until disease progression) for a median of 3 cycles (range, 1-8 cycles). A total of 34 patients received single-agent docetaxel $\left(35 \mathrm{mg} / \mathrm{m}^{2}\right)$, and the remaining 22 patients were treated with docetaxel-based doublets (6 patients received $35 \mathrm{mg} / \mathrm{m}^{2}$ docetaxel plus $100 \mathrm{mg} / \mathrm{m}^{2}$ irinotecan weekly for 3 weeks, every 4 weeks until disease progression; 11 patients received $35 \mathrm{mg} / \mathrm{m}^{2}$ docetaxel weekly for 3 weeks plus $1,000 \mathrm{mg} / \mathrm{m}^{2}$ capecitabine daily for 2 weeks, every 4 weeks until disease progression; and 5 patients received $35 \mathrm{mg} / \mathrm{m}^{2}$ docetaxel weekly for 3 weeks plus $6 \mathrm{mg} / \mathrm{m}^{2}$ hydroxycamptothecin on days 1 and 5 , every 4 weeks until disease progression) for a median of 3 cycles (range, 1-7 cycles). Following progression, 56 patients further received docetaxel-based second-line chemotherapy. A total of 34 patients received single-agent docetaxel, and the remaining 22 patients were treated with docetaxel-based doublets, based on their response to first-line chemotherapy, Eastern Cooperative Oncology Group (ECOG) performance status (PS) and patient consent. Survival was calculated from the starting date of first-line treatment to the date of last follow-up or mortality from any cause. Approval was obtained from the patients and from the ethics committee of Drum Tower Hospital (Nanjing, China).

Gene expression analysis. Gene expression profiling was performed on RNA isolated from macrodissected tumor tissues containing $\geq 80 \%$ of tumor cells, in accordance with a proprietary procedure (European patent publication no. EP1945764-B1). Primers and probes for gene expression analysis of BIM, AEG-1 and AXL are indicated in Table II. The mRNA levels of BIM, AEG-1 and AXL were measured by reverse transcription-quantitative polymerase chain reaction (RT-qPCR) using Taqman ${ }^{\circledR}$ Universal PCR Master Mix (Applied Biosystems; Thermo Fisher Scientific, Inc., Waltham, MA, USA), according to the comparative Cq method (37). $\beta$-actin was used as an endogenous control, and commercial RNA controls (Stratagene; Agilent Technologies, Inc., Santa Clara, CA, USA) were used as calibrators. RT-qPCR was conducted in a 7900HT Fast Real-Time PCR System (Applied Biosystems; Thermo Fisher Scientific, Inc.). The reactions were initiated by heating to $50^{\circ} \mathrm{C}$ for $2 \mathrm{~min}$ and then to $95^{\circ} \mathrm{C}$ for $2 \mathrm{~min}$, followed by 40 cycles of $95^{\circ} \mathrm{C}$ for $15 \mathrm{sec}$ and $60^{\circ} \mathrm{C}$ for $60 \mathrm{sec}$.

Statistical analysis. Gene expression levels were analyzed as categorical variables by terciles. Correlations between gene 
Table I. Patient characteristics.

\begin{tabular}{|c|c|c|c|c|}
\hline Characteristics & $\begin{array}{l}\text { All patients } \\
\mathrm{N}(\%)\end{array}$ & $\begin{array}{l}\text { Patients receiving only } \\
\text { first-line chemotherapy } \\
\qquad \mathrm{N}(\%)\end{array}$ & $\begin{array}{c}\text { Patients receiving } \\
\text { second-line chemotherapy } \\
\mathrm{N}(\%)\end{array}$ & P-value \\
\hline Total, N (\%) & $131(100.0)$ & $75(100.0)$ & $56(100.0)$ & \\
\hline Age, years & & & & 0.330 \\
\hline$<60$ & $63(48.1)$ & $32(42.7)$ & $31(55.4)$ & \\
\hline$\geq 60$ & $68(51.9)$ & $43(57.3)$ & $25(44.6)$ & \\
\hline Gender & & & & 0.410 \\
\hline Female & $31(23.7)$ & $20(26.7)$ & $11(19.6)$ & \\
\hline Male & $100(76.3)$ & $55(73.3)$ & $45(80.4)$ & \\
\hline Tumor site & & & & 0.270 \\
\hline Distal stomach & $50(38.2)$ & $25(33.3)$ & $25(44.6)$ & \\
\hline Proximal stomach & $38(29.0)$ & $24(32.0)$ & $14(25.0)$ & \\
\hline Whole stomach & $42(32.1)$ & $25(33.3)$ & $17(30.4)$ & \\
\hline Unknown & $1(0.8)$ & $1(1.4)$ & $0(0.0)$ & \\
\hline Stage & & & & 0.550 \\
\hline III & $79(60.3)$ & $44(58.7)$ & $35(62.5)$ & \\
\hline IV & $52(39.7)$ & $31(41.3)$ & $21(37.5)$ & \\
\hline ECOG PS & & & & 0.390 \\
\hline $0-1$ & $119(90.8)$ & $66(88.0)$ & 53 (94.6) & \\
\hline 2 & $12(9.2)$ & $9(12.0)$ & $3(5.4)$ & \\
\hline Histological grade & & & & 0.070 \\
\hline G2 & 35 (26.7) & $20(26.7)$ & $15(26.8)$ & \\
\hline G2-3 & 35 (26.7) & $17(22.7)$ & $18(32.1)$ & \\
\hline G3 & $59(45.0)$ & $37(49.3)$ & $22(39.3)$ & \\
\hline Uknown & $2(1.6)$ & $1(1.3)$ & $1(1.3)$ & \\
\hline
\end{tabular}

ECOG, Eastern Cooperative Oncology Group; PS, performance status.

Table II. Sequences of primers and probes.

\begin{tabular}{lll}
\hline Gene & \multicolumn{1}{c}{ Primers } & \multicolumn{2}{c}{ Probes } \\
\hline$\beta$-actin & F 5'-TGAGCGCGGCTACAGCTT-3' & 6-FAM 5'-ACCACCACGGCCGAGCGG-3' TAMRA \\
& R 5'-TCCTTAATGTCACGCACGATTT-3' & \\
AEG-1 & F 5'-GGGGAAGGAGTTGGAGTGAC-3' & 6-FAM 5'-AATATTTTCTGGCATTGGGTCTA-3' MGB \\
& R 5'-GTAGACTGAGAAACTGGCTCAGCAG-3' & \\
AXL & F 5'-CAGCGCAGCCTGCATGT-3' & 6-FAM 5'-CAGGGCTGAACAAGAC-3' MGB \\
& R 5'-GCGTTATGGGCTTCGCAG-3' & \\
BIM & Assay-on-Demand BIM (ID\#Hs00708019_s1) & \\
\hline
\end{tabular}

${ }^{\mathrm{a}}$ Assay-on-Demand BIM (ID\#Hs00708019_s1; catalogue no. 4331182; Life Technologies; Thermo Fisher Scientific, Inc.). ${ }^{\mathrm{b}} \mathrm{AXL}$ is a receptor tyrosine kinase that belongs to the Tyro3, AXL and Mer family. AEG-1, astrocyte elevated gene-1; BIM, B-cell lymphoma 2 interacting mediator of cell death; 6-FAM, 6-carboxyfluorescein; TAMRA, tetramethylrhodamine; MGB, minor groove binder.

expression and clinicopathological parameters were analyzed with the $\chi^{2}$ test. Correlations among different genes were conducted using Spearman's correlation coefficient analysis. Stratified log-rank tests were used to assess the median OS. Estimation of survival curves was performed with the
Kaplan-Meier method. A multivariate analysis was performed using the Cox proportional hazards regression model. All analyses were performed with SPSS version 17.0 software (SPSS, Inc.,Chicago, IL, USA). Two-sided P $<0.05$ was considered to indicate a statistically significant difference. 
Table III. Association between gene expression and clinicopathological characteristics in all patients.

\begin{tabular}{|c|c|c|c|}
\hline Characteristics & $\begin{array}{l}\text { Patients, } \\
\mathrm{N}(\%)\end{array}$ & $\begin{array}{l}\text { Median overall survival, months } \\
\text { (95\% confidence interval) }\end{array}$ & P-value \\
\hline Age, years & & & 0.300 \\
\hline$<60$ & $63(48.1)$ & $12.5(7.8-17.1)$ & \\
\hline$\geq 60$ & $68(51.9)$ & $10.9(8.7-13.0)$ & \\
\hline Gender & & & 0.630 \\
\hline Female & $31(23.7)$ & $11.7(7.2-16.2)$ & \\
\hline Male & $100(76.3)$ & $11.3(8.9-13.6)$ & \\
\hline Tumor site & & & 0.110 \\
\hline Distal stomach & $50(38.2)$ & $11.3(8.9-13.6)$ & \\
\hline Proximal stomach & $38(29.1)$ & $15.9(11.0-20.9)$ & \\
\hline Whole stomach & $42(32.1)$ & $9.9(9.0-10.7)$ & \\
\hline Unknown & $1(0.8)$ & - & \\
\hline Stage & & & 0.001 \\
\hline III & $79(60.3)$ & $12.9(9.1-16.7)$ & \\
\hline IV & $52(39.7)$ & $9.6(7.5-11.6)$ & \\
\hline ECOG PS & & & $<0.001$ \\
\hline $0-1$ & $119(90.8)$ & $12.5(9.9-15.1)$ & \\
\hline 2 & $12(9.2)$ & $6.3(0.7-11.9)$ & \\
\hline Histological grade & & & 0.070 \\
\hline $\mathrm{G} 2$ & $35(26.7)$ & $12.6(2.2-23.0)$ & \\
\hline $\mathrm{G} 2-3$ & $35(26.7)$ & $12.4(7.2-17.6)$ & \\
\hline G3 & $59(45.0)$ & $10.6(9.1-11.1)$ & \\
\hline Unknown & $2(1.6)$ & - & \\
\hline BIM mRNA levels & & & 0.170 \\
\hline Low & $34(25.9)$ & $11.6(8.4-14.7)$ & \\
\hline Intermediate & $35(26.7)$ & $18.2(3.9-32.5)$ & \\
\hline High & $35(26.7)$ & $10.6(8.1-13.0)$ & \\
\hline Not detected & $27(20.7)$ & - & \\
\hline AEG-1 mRNA levels & & & 0.360 \\
\hline Low & $42(32.1)$ & $10.9(8.9-12.8)$ & \\
\hline Intermediate & $40(30.5)$ & $10.0(6.9-13.1)$ & \\
\hline High & $42(32.1)$ & $12.5(9.4-15.7)$ & \\
\hline Not detected & $7(5.3)$ & - & \\
\hline AXL mRNA levels ${ }^{a}$ & & & 0.250 \\
\hline Low & $41(31.3)$ & $12.8(10.9-14.7)$ & \\
\hline Intermediate & $43(32.8)$ & $12.4(7.9-17.0)$ & \\
\hline High & $43(32.8)$ & $10.7(8.9-12.5)$ & \\
\hline Not detected & $4(3.1)$ & - & \\
\hline Second-line chemotherapy & & & 0.060 \\
\hline Yes & $56(42.7)$ & $15.0(8.3-11.9)$ & \\
\hline No & $75(57.3)$ & $10.1(13.0-17.0)$ & \\
\hline
\end{tabular}

${ }^{\mathrm{a}} \mathrm{AXL}$ is a receptor tyrosine kinase that belongs to the Tyro3, AXL and Mer family. ECOG, Eastern Cooperative Oncology Group; PS, performance status; BIM, B-cell lymphoma 2 interacting mediator of cell death; AEG-1, astrocyte elevated gene-1; mRNA, messenger RNA.

\section{Results}

Distribution and clinicopathological features of all patients. A total of 131 advanced GC samples were included in the study, of which, 100 were males and 31 females. The median age of all patients enrolled was 59.6 years (range, 22-84 years). All patients were pathologically confirmed as adenocarcinoma, of which, 79 patients $(60.3 \%)$ were confirmed with stage III and 52 patients (39.7\%) with stage IV disease (Table I). 


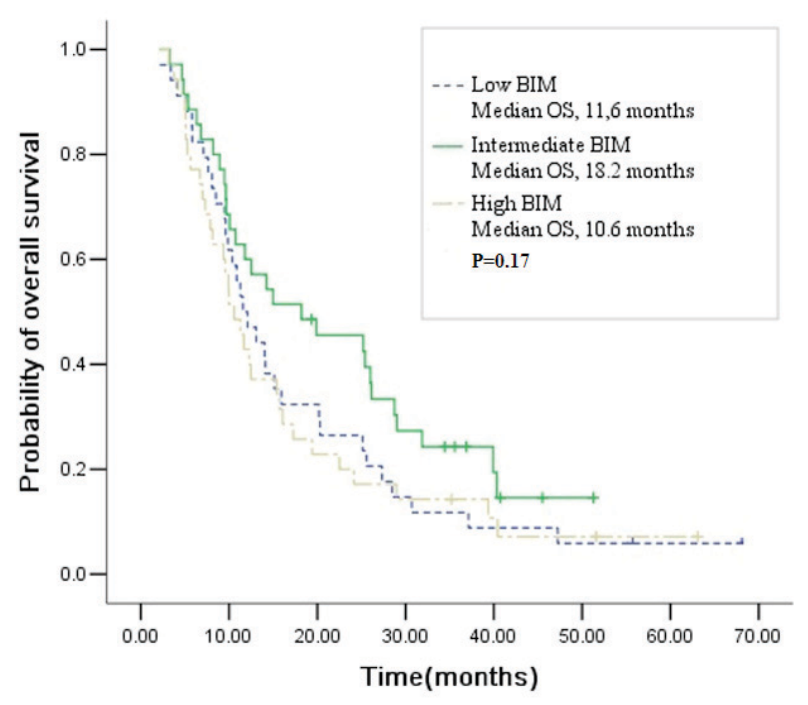

Figure 1. Kaplan-Meier estimates of overall survival in all patients according to the messenger RNA levels of B-cell lymphoma 2 interacting mediator of cell death. BIM, B-cell lymphoma 2 interacting mediator of cell death; OS, overall survival.

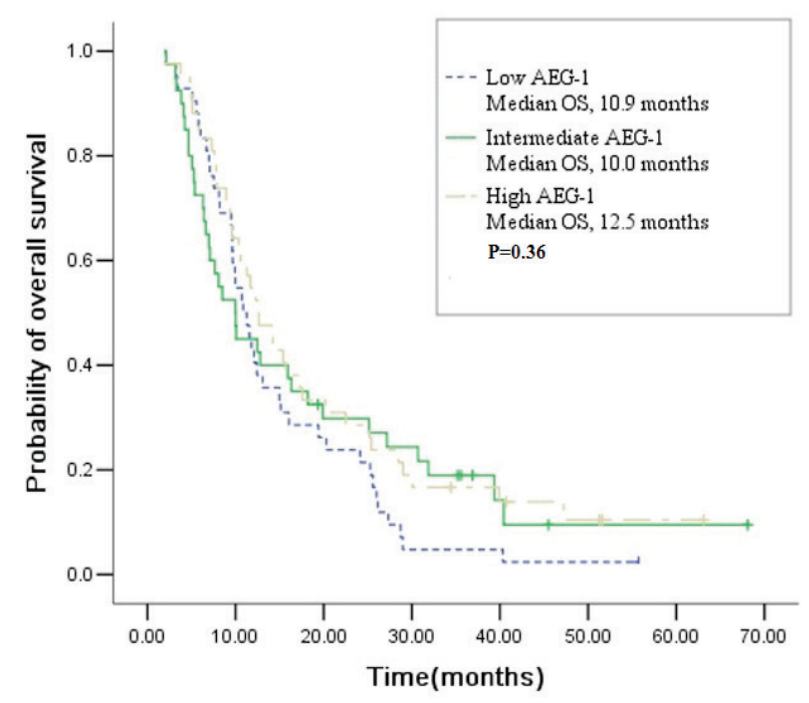

Figure 2. Kaplan-Meier estimates of overall survival in all patients according to the messenger RNA levels of astrocyte elevated gene-1. AEG-1, astrocyte elevated gene-1; OS, overall survival.

Correlations among different genes. A correlation was observed between BIM and AEG-1 mRNA expression $\left(r_{s}=0.30 ; \mathrm{P}=0.002\right)$. However, no associations were observed between BIM, AXL and AEG-1 mRNA expression $(\mathrm{P}=0.100$ and 0.140 respectively).

Association between OS and clinicopathological characteristics. The median OS was 11.6 months (95\% CI, 9.8-13.6) in all patients. Among the patients with stage III disease, the median OS was 12.9 months, compared with 9.6 months among the patients with stage IV disease $(\mathrm{P}=0.001)$. Notably, the median OS was $\sim 12.5$ months for patients with ECOG PS=0-1 vs.

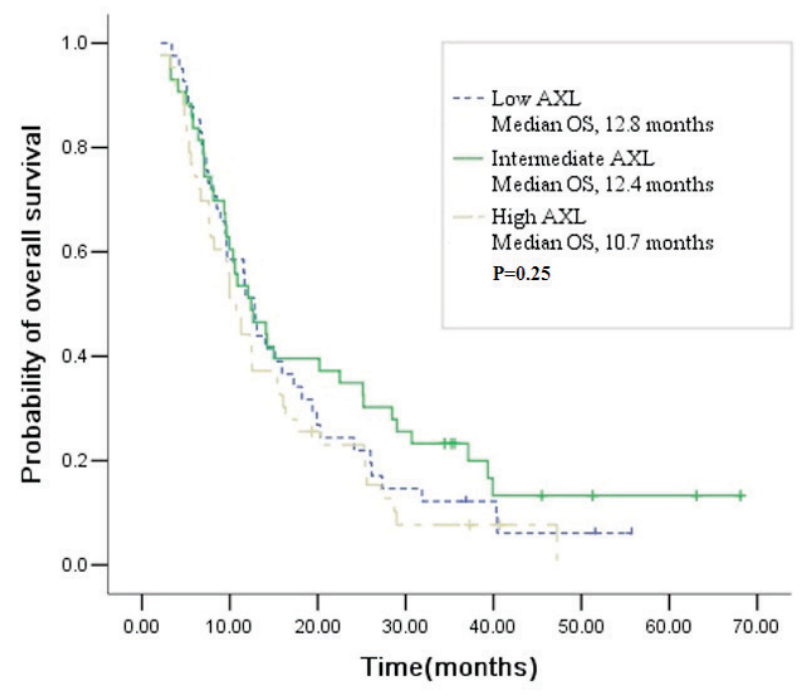

Figure 3. Kaplan-Meier estimates of overall survival in all patients according to the messenger RNA levels of AXL. OS, overall survival.

6.3 months for patients with ECOG PS=2 $(\mathrm{P}<0.001)$. There was no significant association between $\mathrm{OS}$ and age $(\mathrm{P}=0.300)$, gender $(\mathrm{P}=0.630)$, tumor site $(\mathrm{P}=0.110)$ or histological grade $(\mathrm{P}=0.070)$ (Table III).

Survival for GC patients according to mRNA expression levels. No association was observed between $\mathrm{OS}$ and the mRNA expression levels of BIM $(\mathrm{P}=0.170)$, AEG-1 $(\mathrm{P}=0.360)$ and AXL $(\mathrm{P}=0.250)$ in all 131 patients, respectively (Figs. 1-3).

Among the 75 patients receiving only first-line FOLFOX chemotherapy, a trend towards longer survival was observed in those with low BIM levels $(\mathrm{P}=0.080)$. However, there was no difference in survival according to their AEG-1 $(\mathrm{P}=0.810)$ or AXL mRNA expression levels $(\mathrm{P}=0.350)$.

Among the 56 patients receiving additional docetaxel-based second-line chemotherapy, the median OS was 9.6 months (95\% CI, 8.9-10.3) for patients with low levels of BIM, 25.2 months (95\% CI, 12.5-37.9) for those with intermediate BIM levels and 15.7 months (95\% CI, 9.4-22.0) for those with high BIM levels $(\mathrm{P}=0.021)$. Considering the obvious trend of a longer OS in patients with higher BIM expression, high and intermediate expression groups were merged into a whole group for further analysis (Fig. 4). Patients with high or intermediate levels of BIM exhibited a median OS of 18.2 months (95\% CI, 12.8-23.6), while patients with low BIM exhibited a median OS of just 9.6 months (95\% CI, 8.9-10.3; $\mathrm{P}=0.008)$. Longer survival was also observed in patients with high levels of AEG-1 $(\mathrm{P}=0.080)$, although the difference was not significant. There was no difference in OS according to the expression levels of AXL $(\mathrm{P}=0.600)$.

To further understand the role of BIM as a predictive biomarker, multivariate analysis of OS was performed. Patients with low BIM mRNA levels had higher mortality than those with high or intermediate BIM mRNA levels (HR of mortality, 2.61; 95\% CI, 1.21-5.62; $\mathrm{P}=0.010)$. Lower risk of mortality was observed in patients with ECOG PS=0-1 compared with those with ECOG PS=2 (HR, 0.17; 95\% CI, 0.04-0.65; P=0.010) in patients with stage III tumors, compared with patients with 


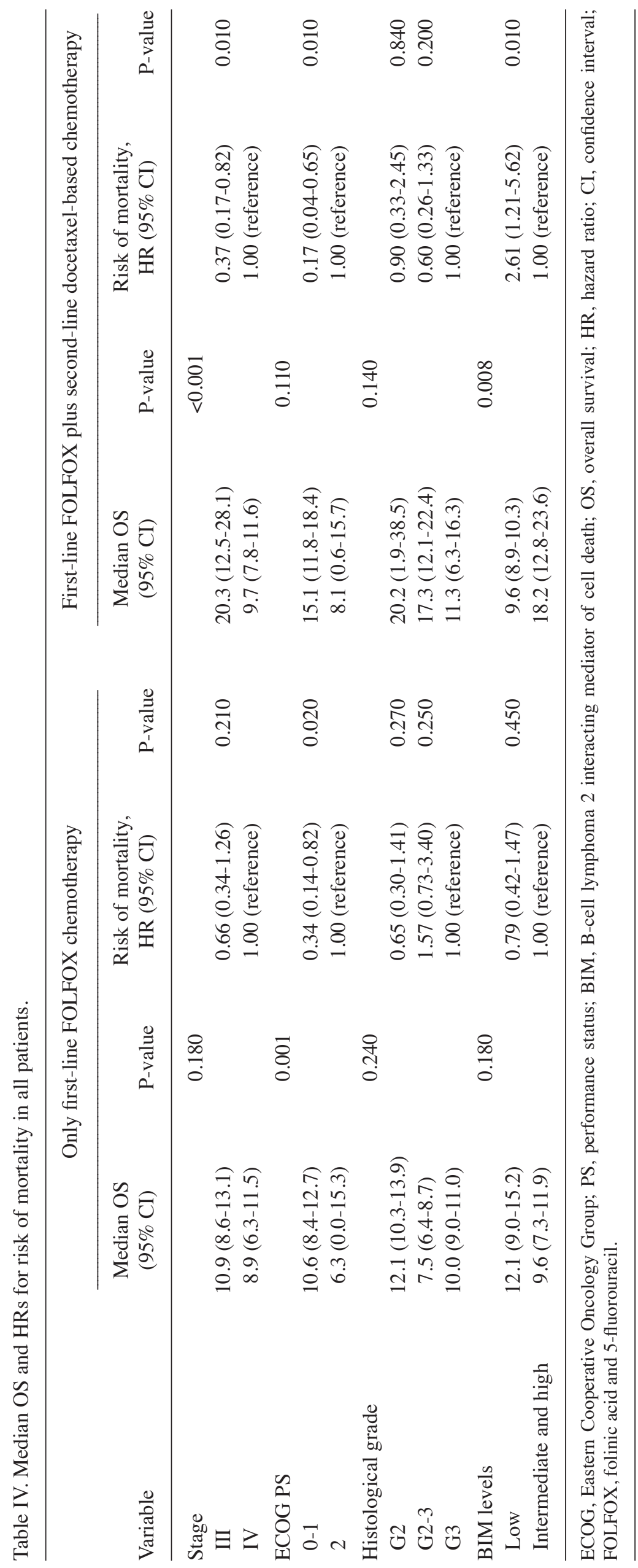




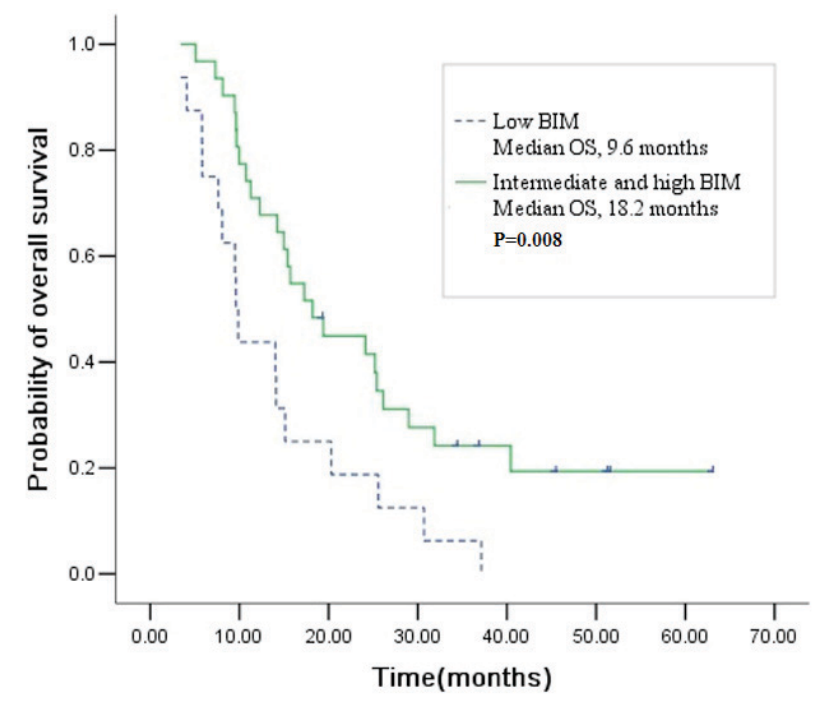

Figure 4. Kaplan-Meier estimates of overall survival in patients receiving docetaxel-based second-line chemotherapy according to the messenger RNA levels of B-cell lymphoma 2 interacting mediator of cell death. BIM, B-cell lymphoma 2 interacting mediator of cell death; OS, overall survival.

stage IV tumors (HR, 0.37; 95\% CI, 0.17-0.82; $\mathrm{P}=0.010)$ (Table IV).

\section{Discussion}

Following the failure of first-line chemotherapy, several drugs are recommended for second-line regimens, including paclitaxel, docetaxel and irinotecan (38). The median OS of patients receiving second-line docetaxel-based regimens ranges from 3.5 to 10.9 months, which is still dismal (5). The present authors previously observed that GC patients with high BRCA1 levels could benefit from receiving second-line docetaxel-based chemotherapy (6). In addition, the median OS was further prolonged for patients with high levels of BRCA1 and multiple myeloma SET domain (39).

The DNA damage caused by chemotherapy leads to cell cycle arrest, DNA repair or commitment to apoptosis (40). Failure of drug-induced apoptosis is a vital reason for chemoresistance (41). A previous study identified that overexpression of genes involved in apoptosis appeared to contribute to docetaxel sensitivity in breast cancer through high-throughput screening of thousands of genes (42). It is commonly known that taxanes interfere with the dynamics of the microtubules and induce apoptosis through the mitochondrial apoptotic pathway (43).

In the present study, a marked difference in OS (18.2 vs. 9.6 months) was observed in patients receiving second-line docetaxel-based chemotherapy, according to their BIM mRNA expression levels in univariate analysis $(\mathrm{P}=0.008)$. In addition, this association was also significant in multivariate analysis, which further confirmed the role of BIM as a predictive biomarker. Patients with low BIM mRNA levels exhibited higher mortality than those with high or intermediate BIM mRNA levels (HR, 2.61; 95\% CI, 1.21-5.62; $\mathrm{P}=0.010$ ). These results were consistent with previously published data suggesting that overexpression of BIM was accompanied by a collateral increase in sensitivity to taxanes (19), which may translate into prolonged OS.

BIM is an important mediator of tumor cell death (15). Other studies have previously demonstrated that several kinase-driven tumors, including chronic myelogenous leukemia and NSCLC, maintain a survival advantage by suppressing BIM transcription and by targeting BIM protein for proteasomal degradation (44-46). Numerous studies have clearly demonstrated that activation of the PI3K/AKT signaling pathway could regulate BIM expression $(44,47)$. The PI3K/AKT signaling pathway triggers a cascade of cell responses, including cell cycle progression, programmed cell death and DNA damage repair in cancer (48). Furthermore, the PI3K/AKT signaling pathway is closely associated with the development and recurrence of cancer (49). The class $\mathrm{O}$ of forkhead box (FOXO) transcription factors are downstream effectors of the PI3K/AKT signaling pathway (50). When active, FOXOs induce cell cycle arrest and apoptosis, acting as anti-proliferative factors (51). BIM is mainly regulated by FOXO3a, a member of the FOXO family (52). Following an apoptotic-stress event, BIM translocates to the mitochondria, and is essential to mediate the release of cytochrome $c$ from the mitochondria, which in turn activates the effector caspase-9 and the formation of the apoptosome (53). Previous studies reported that the PI3K inhibitor LY294002 could increase BIM expression and cell death, which partly demonstrated a modulating role of PI3K/AKT signaling on BIM expression (47). The aforementioned results are in agreement with the pattern of FOXO3a dephosphorylation and nuclear translocation. The dephosphorylation status of AKT inhibits the nuclear export of its substrate FOXO3a to the cytoplasm, which transactivates the main target gene, BIM, to cause cell cycle arrest and cell death (52). In a previous study, BIM mRNA levels could be increased by upregulation of FOXO3a following paclitaxel treatment, leading to apoptosis in breast cancer cells and contributing to tumor sensitivity to paclitaxel (54). Thus, the impact of BIM and other BH3-only proteins in GC patients through apoptosis pathways should be further investigated.

AEG-1 was identified as an oncogene that caused detrimental effects to patients' OS through preventing cancer cells from undergoing apoptosis (55). Overexpression of AEG-1 leads to the activation of the PI3K/AKT pro-survival signaling pathway and the downregulation of BCL-2 associated agonist of cell death (BAD), p21, p27 and FOXO3a (24). In addition, increasing expression and activation of FOXO3a by AEG-1 knockdown further confirms this mechanism (56). AXL, a receptor tyrosine kinase, was originally cloned from cancer cells (57). A crucial step in AXL-dependent signal transduction is the activation of PI3K/AKT (58). The activation of AXL protects cells from apoptosis and increases the expression of the anti-apoptotic proteins BCL-2 and BCL-XL (59), as well as the phosphorylation of BAD (60). AXL is also implicated in angiogenesis (61) and immune response (62). Preclinical findings and retrospective studies have illustrated that overexpression of AEG-1 and AXL confers broad drug resistance to chemotherapeutic agents, including paclitaxel (63), cisplatin $(64,65)$ and 5-FU (27). However, no correlations were observed in the present study between AEG-1 and AXL mRNA expression levels and patients' outcome to chemotherapy, either in first-line or second-line chemotherapy. This reflects 
the complexity of tumor drug response and the fact that single genes may not be sufficient to predict the therapeutic effect.

The present study has certain limitations. First, the number of patients included in the study is relatively small, which may cause bias in data analysis. In addition, the study is retrospective in nature. Furthermore, multiple gene models or signatures may be more effective than single biomarkers, as gene expression patterns associated with drug resistance and sensitivity are complex.

In conclusion, based on the significantly prolonged OS among patients with high or intermediate BIM mRNA expression in the present study, BIM may act as a potential biomarker in second-line docetaxel-based chemotherapy for GC. The findings in the current study pave the way for personalized chemotherapy in GC.

\section{Acknowledgements}

The present study was funded by grants from the National Natural Science Foundation of China (Beijing, China; grant no. 81000980, 81220108023 and 81370064), the Fundamental Research Funds for the Central Universities (Beijing, China; grant no. 20620140729), the Jiangsu Provincial Program of Medical Science (Nanjing, China; grant no. BL2012001) and the Distinguished Young Investigator Project of Nanjing (Nanjing, China; grant no. JQX12002).

\section{References}

1. Fock KM: Review article: The epidemiology and prevention of gastric cancer. Aliment Pharmacol Ther 40: 250-260, 2014.

2. Wadhwa R, Song S, Lee JS, Yao Y, Wei Q and Ajani JA: Gastric cancer-molecular and clinical dimensions. Nat Rev Clin Oncol 10: 643-655, 2013.

3. Wagner AD, Grothe W, Haerting J, Kleber G, Grothey A and Fleig WE: Chemotherapy in advanced gastric cancer: A systematic review and meta-analysis based on aggregate data. J Clin Oncol 24: 2903-2909, 2006.

4. Ji SH, Lim DH, Yi SY, Kim HS, Jun HJ, Kim KH, Chang MH, Park MJ, Uhm JE, Lee J, et al: A retrospective analysis of second-line chemotherapy in patients with advanced gastric cancer. BMC Cancer 9: 110, 2009.

5. Wesolowski R, Lee C and Kim R: Is there a role for second-line chemotherapy in advanced gastric cancer? Lancet Oncol 10: 903-912, 2009.

6. Wei J, Costa C, Ding Y, Zou Z, Yu L, Sanchez JJ, Qian X, Chen H, Gimenez-Capitan A, Meng F, et al: mRNA expression of BRCA1, PIAS1, and PIAS4 and survival after second-line docetaxel in advanced gastric cancer. J Natl Cancer Inst 103: 1552-1556, 2011.

7. Yang X, Fraser M, Moll UM, Basak A and Tsang BK: Akt-mediated cisplatin resistance in ovarian cancer: Modulation of p53 action on caspase-dependent mitochondrial death pathway. Cancer Res 66: 3126-3136, 2006.

8. Yuan Z, Wang F, Zhao Z, Zhao X, Qiu J, Nie C and Wei Y: BIM-mediated AKT phosphorylation is a key modulator of arsenic trioxide-induced apoptosis in cisplatin-sensitive and-resistant ovarian cancer cells. PLoS One 6: e20586, 2011.

9. Asselin E, Mills GB and Tsang BK: XIAP regulates Akt activity and caspase-3-dependent cleavage during cisplatin-induced apoptosis in human ovarian epithelial cancer cells. Cancer Res 61: 1862-1868, 2001.

10. Jamieson ER and Lippard SJ: Structure, recognition, and processing of cisplatin-DNA adducts. Chem Rev 99: 2467-2498, 1999.

11. Kelland L: The resurgence of platinum-based cancer chemotherapy. Nat Rev Cancer 7: 573-584, 2007.

12. Alberti C: Taxane- and epothilone-based chemotherapy: from molecule cargo cytoskeletal logistics to management of castration-resistant prostate carcinoma. Eur Rev Med Pharmacol Sci 17: 1658-1664, 2013.
13. Zheng JH, Viacava Follis A, Kriwacki RW and Moldoveanu T: Discoveries and controversies in BCL-2 protein-mediated apoptosis. FEBS J 283: 2690-2700, 2016.

14. Correia C, Lee SH, Meng XW, Vincelette ND, Knorr KL, Ding H, Nowakowski GS, Dai H and Kaufmann SH: Emerging understanding of Bcl-2 biology: Implications for neoplastic progression and treatment. Biochim Biophys Acta 1853: 1658-1671, 2015.

15. Iurlaro R and Muñoz-Pinedo C: Cell death induced by endoplasmic reticulum stress. FEBS J 283: 2640-2652, 2016.

16. Crawford N, Chacko AD, Savage KI, McCoy F, Redmond K, Longley DB and Fennell DA: Platinum resistant cancer cells conserve sensitivity to $\mathrm{BH} 3$ domains and obatoclax induced mitochondrial apoptosis. Apoptosis 16: 311-320, 2011.

17. Simonin K, N'Diaye M, Lheureux S, Loussouarn C, Dutoit S, Briand M, Giffard F, Brotin E, Blanc-Fournier C and Poulain L: Platinum compounds sensitize ovarian carcinoma cells to ABT-737 by modulation of the Mcl-1/Noxa axis. Apoptosis 18: 492-508, 2013.

18. Inoue Y, Gika M, Abiko T, Oyama T, Saitoh Y, Yamazaki H, Nakamura M, Abe Y, Kawamura M and Kobayashi K: Bcl-2 overexpression enhances in vitro sensitivity against docetaxel in non-small cell lung cancer. Oncol Rep 13: 259-264, 2005.

19. Savry A, Carre M, Berges R, Rovini A, Pobel I, Chacon C, Braguer D and Bourgarel-Rey V: Bcl-2-enhanced efficacy of microtubule-targeting chemotherapy through Bim overexpression: Implications for cancer treatment. Neoplasia 15: 49-60, 2013.

20. Faber AC, Corcoran RB, Ebi H, Sequist LV, Waltman BA, Chung E, Incio J, Digumarthy SR, Pollack SF, Song Y, et al: BIM expression in treatment-naive cancers predicts responsiveness to kinase inhibitors. Cancer Discov 1: 352-365, 2011.

21. Costa C, Molina MA, Drozdowskyj A, Giménez-Capitán A, Bertran-Alamillo J, Karachaliou N, Gervais R, Massuti B, Wei J, Moran T, et al: The impact of EGFR T790M mutations and BIM mRNA expression on outcome in patients with EGFR-mutant NSCLC treated with erlotinib or chemotherapy in the randomized phase III EURTAC trial. Clin Cancer Res 20: 2001-2010, 2014.

22. Su ZZ, Kang DC, Chen Y, Pekarskaya O, Chao W, Volsky DJ and Fisher PB: Identification and cloning of human astrocyte genes displaying elevated expression after infection with HIV-1 or exposure to HIV-1 envelope glycoprotein by rapid subtraction hybridization, RaSH. Oncogene 21: 3592-3602, 2002.

23. Hu G, Wei Y and Kang Y: The multifaceted role of MTDH/AEG-1 in cancer progression. Clin Cancer Res 15: 5615-5620, 2009.

24. Lee SG, Su ZZ, Emdad L, Sarkar D, Franke TF and Fisher PB: Astrocyte elevated gene-1 activates cell survival pathways through PI3K-Akt signaling. Oncogene 27: 1114-1121, 2008.

25. Jian-bo X, Hui W, Yu-long H, Chang-hua Z, Long-juan Z, Shi-rong C and Wen-hua Z: Astrocyte-elevated gene-1 overexpression is associated with poor prognosis in gastric cancer. Med Oncol 28: 455-462, 2011.

26. Song L, Li W, Zhang H, Liao W, Dai T, Yu C, Ding X, Zhang L and Li J: Over-expression of AEG-1 significantly associates with tumour aggressiveness and poor prognosis in human non-small cell lung cancer. J Pathol 219: 317-326, 2009.

27. Yoo BK, Gredler R, Vozhilla N, Su ZZ, Chen D, Forcier T, Shah K, Saxena U, Hansen U, Fisher PB and Sarkar D: Identification of genes conferring resistance to 5-fluorouracil. Proc Natl Acad Sci USA 106: 12938-12943, 2009.

28. Santarpia M,MagriI, Sanchez-Ronco M,Costa C,Molina-VilaMA, Gimenez-Capitan A, Bertran-Alamillo J, Mayo C, Benlloch S, Viteri $\mathrm{S}$, et al: mRNA expression levels and genetic status of genes involved in the EGFR and NF-kB pathways in metastatic non-small-cell lung cancer patients. J Transl Med 9: 163, 2011.

29. Graham DK, DeRyckere D, Davies KD and Earp HS: The TAM family: Phosphatidylserine sensing receptor tyrosine kinases gone awry in cancer. Nat Rev Cancer 14: 769-785, 2014.

30. van der Meer JH, van der Poll T and van 't Veer C: TAM receptors, Gas6, and protein S: roles in inflammation and hemostasis. Blood 123: 2460-2469, 2014

31. Papadakis ES, Cichoń MA, Vyas JJ, Patel N, Ghali L, Cerio R, Storey A and O'Toole EA: Axl promotes cutaneous squamous cell carcinoma survival through negative regulation of pro-apoptotic Bcl-2 family members. J Invest Dermatol 131: 509-517, 2011.

32. Verma A, Warner SL, Vankayalapati H, Bearss DJ and Sharma S: Targeting Axl and Mer kinases in cancer. Mol Cancer Ther 10: 1763-1773, 2011.

33. Ou WB, Corson JM, Flynn DL, Lu WP, Wise SC, Bueno R, Sugarbaker DJ and Fletcher JA: AXL regulates mesothelioma proliferation and invasiveness. Oncogene 30: 1643-1652, 2011. 
34. Wimmel A, Glitz D, Kraus A, Roeder J and Schuermann M: Axl receptor tyrosine kinase expression in human lung cancer cell lines correlates with cellular adhesion. Eur J Cancer 37: 2264-2274, 2001.

35. Berclaz G, Altermatt HJ, Rohrbach V, Kieffer I, Dreher E and Andres AC: Estrogen dependent expression of the receptor tyrosine kinase axl in normal and malignant human breast. Ann Oncol 12: 819-824, 2001.

36. Macleod K, Mullen P, Sewell J, Rabiasz G, Lawrie S, Miller E, Smyth JF and Langdon SP: Altered ErbB receptor signaling and gene expression in cisplatin-resistant ovarian cancer. Cancer Res 65: 6789-6800, 2005.

37. Bubner B and Baldwin IT: Use of real-time PCR for determining copy number and zygosity in transgenic plants. Plant Cell Rep 23: 263-271, 2004.

38. Elimova E, Shiozaki H, Wadhwa R, Sudo K, Chen Q, Estrella JS, Blum MA, Badgwell B, Das P, Song S and Ajani JA: Medical management of gastric cancer: A 2014 update. World J Gastroenterol 20: 13637-13647, 2014.

39. Wei J, Costa C, Shen J, Yu L, Sanchez J, Qian X, Sun X, Zou Z, Gimenez-Capitan A, Yue G, et al: Differential effect of MMSET mRNA levels on survival to first-line FOLFOX and second-line docetaxel in gastric cancer. Br J Cancer 110: 2662-2668, 2014

40. Pan ST, Li ZL, He ZX, Qiu JX and Zhou SF: Molecular mechanisms for tumour resistance to chemotherapy. Clin Exp Pharmacol Physiol 43: 723-737, 2016.

41. Cree IA and Charlton P: Molecular chess? Hallmarks of anti-cancer drug resistance. BMC cancer 17: 10, 2017.

42. Chang JC, Wooten EC, Tsimelzon A, Hilsenbeck SG, Gutierrez MC, Elledge R, Mohsin S, Osborne CK, Chamness GC, Allred DC and O'Connell P: Gene expression profiling for the prediction of therapeutic response to docetaxel in patients with breast cancer. Lancet 362: 362-369, 2003.

43. Kang BW, Kwon OK, Chung HY, Yu W and Kim JG: Taxanes in the rreatment of advanced gastric cancer. Molecules 21: E651, 2016.

44. Costa DB, Halmos B, Kumar A, Schumer ST, Huberman MS, Boggon TJ, Tenen DG and Kobayashi S: BIM mediates EGFR tyrosine kinase inhibitor-induced apoptosis in lung cancers with oncogenic EGFR mutations. PLoS Med 4: 1669-1680, 2007.

45. Gong Y, Somwar R, Politi K, Balak M, Chmielecki J, Jiang X and Pao W: Induction of BIM is essential for apoptosis triggered by EGFR kinase inhibitors in mutant EGFR-dependent lung adenocarcinomas. PLoS Med 4: e294, 2007.

46. Kuroda J, Puthalakath H, Cragg MS, Kelly PN, Bouillet P, Huang DC, Kimura S, Ottmann OG, Druker BJ, Villunger A, et al: $\mathrm{Bim}$ and $\mathrm{Bad}$ mediate imatinib-induced killing of $\mathrm{Bcr} / \mathrm{Abl}^{+}$ leukemic cells, and resistance due to their loss is overcome by a BH3 mimetic. Proc Natl Acad Sci USA 103: 14907-14912, 2006.

47. Qi XJ, Wildey GM and Howe PH: Evidence that Ser87 of BimEL is phosphorylated by Akt and regulates BimEL apoptotic function. J Biol Chem 281: 813-823, 2006.

48. Brown JS and Banerji U: Maximising the potential of AKT inhibitors as anti-cancer treatments. Pharmacol Ther: December 2, 2016 (Epub ahead of print).

49. Sun Y, Tian H, Wang L and Yang $\mathrm{H}$ : The effects of silencing of PI3K p $85 \alpha$ on 5 -FU-induced colorectal cancer cells apoptosis. Med Oncol 30: 704, 2013.
50. Carbajo-Pescador S, Mauriz JL, García-Palomo A and González-Gallego J: FoxO proteins: Regulation and molecular targets in liver cancer. Curr Med Chem 21: 1231-1246, 2014.

51. Fernández de Mattos S, Villalonga P, Clardy J and Lam EW: FOXO3a mediates the cytotoxic effects of cisplatin in colon cancer cells. Mol Cancer Ther 7: 3237-3246, 2008

52. Vogiatzi P, De Falco G, Claudio PP and Giordano A: How does the human RUNX3 gene induce apoptosis in gastric cancer? Latest data, reflections and reactions. Cancer Biol Ther 5: 371-374, 2006.

53. Piñon JD, Labi V, Egle A and Villunger A: Bim and Bmf in tissue homeostasis and malignant disease. Oncogene 27 (Suppl 1): S41-S52, 2008.

54. Sunters A, Fernández de Mattos S, Stahl M, Brosens JJ, Zoumpoulidou G, Saunders CA, Coffer PJ, Medema RH, Coombes RC and Lam EW: FoxO3a transcriptional regulation of Bim controls apoptosis in paclitaxel-treated breast cancer cell lines. J Biol Chem 278: 49795-49805, 2003.

55. Hu G, Wei Y and Kang Y: The multifaceted role of MTDH/AEG-1 in cancer progression. Clin Cancer Res 15: 5615-5620, 2009.

56. Wilson MS, Brosens JJ, Schwenen HD and Lam EW: FOXO and FOXM1 in cancer: The FOXO-FOXM1 axis shapes the outcome of cancer chemotherapy. Curr Drug Targets 12: 1256-1266, 2011.

57. Lemke G: Biology of the TAM receptors. Cold Spring Harb Perspect Biol 5: a009076, 2013.

58. Li Y, Jia L, Ren D, Liu C, Gong Y, Wang N, Zhang X and Zhao Y: Axl mediates tumor invasion and chemosensitivity through PI3K/Akt signaling pathway and is transcriptionally regulated by slug in breast carcinoma. IUBMB Life 66: 507-518, 2014.

59. Hasanbasic I, Cuerquis J, Varnum B and Blostein MD: Intracellular signaling pathways involved in Gas6-Axl-mediated survival of endothelial cells. Am J Physiol Heart Circ Physiol 287: H1207-H1213, 2004.

60. Goruppi S, Ruaro E, Varnum B and Schneider C: Gas6-mediated survival in NIH3T3 cells activates stress signalling cascade and is independent of Ras. Oncogene 18: 4224-4236, 1999.

61. Holland SJ, Powell MJ, Franci C, Chan EW, Friera AM, Atchison RE, McLaughlin J, Swift SE, Pali ES, Yam G, et al: Multiple roles for the receptor tyrosine kinase axl in tumor formation. Cancer Res 65: 9294-9303, 2005.

62. Tjwa M, Bellido-Martin L, Lin Y, Lutgens E, Plaisance S, Bono F, Delesque-Touchard N, Hervé C, Moura R, Billiau AD, et al: Gas6 promotes inflammation by enhancing interactions between endothelial cells, platelets, and leukocytes. Blood 111: 4096-4105, 2008.

63. Hu G, Chong RA, Yang Q, Wei Y, Blanco MA, Li F, Reiss M, $\mathrm{Au}$ JL, Haffty BG and Kang Y: MTDH activation by $8 \mathrm{q} 22$ genomic gain promotes chemoresistance and metastasis of poor-prognosis breast cancer. Cancer Cell 15: 9-20, 2009.

64. Li C, Li Y, Wang X, Wang Z, Cai J, Wang L, Zhao Y, Song H, Meng X, Ning X, et al: Elevated expression of astrocyte elevated gene-1 (AEG-1) is correlated with cisplatin-based chemoresistance and shortened outcome in patients with stages III-IV serous ovarian carcinoma. Histopathology 60: 953-963, 2012.

65. Hong J, Peng D, Chen Z, Sehdev V and Belkhiri A: ABL regulation by AXL promotes cisplatin resistance in esophageal cancer. Cancer Res 73: 331-340, 2013. 